\title{
ANALISIS PENEMPATAN DAN DESAIN BANGUNAN PENGENDALI SEDIMEN GUNA PENANGANAN LAJU EROSI DI DAS OESAPA BESAR KUPANG PROVINSI NUSA TENGGARA TIMUR
}

\author{
Sutirto $^{1}$, Dian E.W. Johannis ${ }^{2}$, Yunus Falo ${ }^{3}$
}

\begin{abstract}
Abstrak :
Hasil analisa existing DAS Oesapa Besar pada tahun 2015 mempunyai laju erosi 425,771 ton/ha/tahun dan total besarnya erosi 53.662,426 ton/tahun dengan ketebalan erosi lahan 5,6 mm/tahun. Tingkat bahaya erosi dan kekritisan lahan dengan kriteria Sangat ringan 1.901,86 Ha (41,33), Sedang 1,524,79 Ha (33,13\%), Berat 601,41 Ha (13,07\%) dan Sangat Berat seluas 573, $70 \mathrm{Ha}$ (12,47\%). Untuk menjaga besarnya debit limpasan dan laju erosi yang sangat besar di DAS Oesapa Besar diperlukan desain bangunan pengendali sedimen sesuai kondisi eksisting Desain bangunan (check dam) yang dilakukan dalam rangka menghasilkan suatu bangunan fungsional yang optimal dengan total biaya minimum. Untuk mencapai biaya minimum tersebut, maka check dam harus didesain dengan memanfaatkan material yang tersedia secara maksimum, termasuk material galian dan urugan untuk pondasi dan untuk bangunan pelengkap.Dari hasil analisa sesuai arahan penempatan lokasi bangunan pengendali sedimen diperoleh 9 lokasi untuk menahan laju erosi yang terjadi di DAS Oesapa Besar. Adapun usia masing-masing bangunan pengendali sedimen sesuai penempatan dan laju erosi yang terjadi pada Sub-Sub DAS Oesapa Besar yang dapat menahan laju erosi sebesar 420,383 ton/ha/tahun melalui daya tampung sedimen yang di tampung oleh bangunan pengendali sedimen 478.324,89 ton dengan kurun waktu selama 27 tahun.
\end{abstract}

Kata Kunci : Laju Erosi, Bangunan Pengendali Sedimen, Kurun waktu 27 tahun.

\section{PENDAHULUAN}

Hasil penelitian sebelumnya tentang" Analisis Laju Erosi Menggunakan Sistem Informasi Geogradi (SIG) di DAS Oesapa Besar Kupang Provinsi Nusa Tenggara Timur" Debit Limpasan yang terjadi di DAS Oesapa Besar kondisi di lapangan pada tahun 2013 dengan kala ulang $\mathrm{Q}_{1,01 \text { Tahun }}=33.60 \mathrm{~m}^{3} / \mathrm{dt}, \mathrm{Q}_{2 \text { Tahun }}=$ $65.10 \mathrm{~m}^{3} / \mathrm{dt} \mathrm{Q}_{5 \text { Tahun }} 86.60 \mathrm{~m}^{3} / \mathrm{dt} \mathrm{Q}_{10 \text { Tahun }} 101.55$ $\mathrm{m}^{3} / \mathrm{dt}, \mathrm{Q}_{25 \text { Tahun }} 121.31 \mathrm{~m}^{3} / \mathrm{dt}$ Adapun Laju Erosi yang terjadi di DAS Oesapa Besar yang mempunyai luas total keseluruhan 46.017.500 $\mathrm{m}^{2}$ atau $4.601,75 \mathrm{Ha}$ didalamnya terdiri atas SubSub DAS sebanyak 74 (tujuh puluh empat) dengan laju erosi pada tahun 2013 sebesar 425,771 ton/ha.

Melihat besar debit limpasan dan laju erosi yang sangat besar di DAS Oesapa Besar lambat laun akan mengakibatkan bencana besar bagi Wilayah terutama di Kabupaten Kupang dan Kota Kupang yang menjadi Central Pemerin tahan di Wilayah Propinsi Nusa Tenggara Timur. Dengan permasalahan tersebut diatas seperti permasalahan lingkungan dan ketersediaan 
lahan, serta tingkat erosi lahan yang tinggi diperlukan kajian untuk membuat suatu upaya melalui bangunan civil teknis guna memperkecil debit limpasan dan laju erosi yang terjadi di DAS Oeapa Besar dalam setiap tahunnya dengan tujuan kelestarian daerah tangkapan air di Kota Kupang dapat terjaga, serta mencegah kerusakan ekosistem dan bencana alam yang lebih besar.

\section{LANDASAN TEORI}

\section{a.Pendugaan Laju Erosi Berdasarkan} Metode MUSLE / MPUKT

Untuk memperkirakan besarnya erosi dalam studi ini menggunakan metode MUSLE (Modified Universal Soil Loss Equation) atau MPUKT (Modifikasi Persamaan Umum Kehilangan Tanah). Metode ini merupakan modifikasi dari USLE (Universal Soil Loss Equation) atau PUKT (Persamaan Umum Kehilangan Tanah) yang dikembangkan oleh Williams (1995).

Adapun persamaan MUSLE (William, 1975) adalah sebagai berikut :

$\mathrm{A}=\mathrm{Rw} \times \mathrm{K} \times \mathrm{L} \times \mathrm{S} \times \mathrm{C} \times \mathrm{P}$

Dimana :

A = Besarnya kehilangan tanah per satuan luas lahan (ton/ha)

$\mathrm{Rw}=$ Indeks erosivitas limpasan permukaan (mm).

$\mathrm{K}=$ Indeks erodibilitas tanah.

$\mathrm{L} \quad=$ Faktor panjang lereng.

$\mathrm{S} \quad=$ Faktor kemiringan lereng.

$\mathrm{C}=$ Faktor tanaman/ faktor vegetasi penutup tanah.

$\mathrm{P} \quad=$ Faktor tindakan pengelolaan tanaman.

\section{b. Indeks Erosivitas Limp. Permukaan (Rw)}

Indeks erosivitas untuk pendugaan besarnya laju erosi dapat dihitung dengan analisa Rw menurut Williams. Rumus ini digunakan pada daerah aliran yang cukup luas, selama erosi juga terjadi pengendapan dalam proses pengangkutan. Hasil endapan dipengaruhi oleh limpasan permukaan. Dalam rumus ini, William menga- dakan Modifikasi PUKT untuk menduga hasil endapan dari setiap kejadian limpasan permukaan dengan cara mengganti indeks erosivitas (R) dengan erosivitas limpasan permukaan $(\mathrm{Rw})$.

$\mathrm{Rw}=9,05 .(\text { Vo. Qp })^{0,56}$

Dimana:

$$
\begin{aligned}
& \mathrm{Vo}=\mathrm{R} \cdot \exp (-\mathrm{Rc} / \mathrm{Ro}) \\
& \mathrm{Rc}=1000 . \mathrm{Ms} \cdot \mathrm{BD} \cdot \mathrm{RD} .(\mathrm{Et} / \mathrm{Eo})^{0,50} \\
& \mathrm{Ro}=\mathrm{R} / \mathrm{Rn}
\end{aligned}
$$

Dengan :

$\mathrm{RW}=$ Indeks erosivitas limpasan permukaan $\left(\mathrm{m}^{2} / \mathrm{jam}\right)$

Vo = Volume limpasan permukaan $\left(\mathrm{m}^{3} / \mathrm{ha}\right)$

$\mathrm{Qp}=$ Laju maks. aliran air permukaan $\left(\mathrm{m}^{3} /\right.$ $\operatorname{det} / \mathrm{ha})$

$\mathrm{R}=$ Jumlah curah hujan bulanan

Ro = Hujan satuan (mm)

Ms = Kandungan lengas pada kapasitas lapang (\%)

$\mathrm{BD}=$ Berat jenis volume lapisan tanah atas $\left(\mathrm{mg}^{3} / \mathrm{m}\right)$

$\mathrm{RD}=$ Kedalaman perakaran efektif $(\mathrm{m})$, didefinisikan sebagai lapisan Impermeable. Besarnya ditentukan sebagai berikut :

- Untuk tanaman pohon, tanaman kayu $=0,10$

- Untuk tanaman semusim dan rumput $=0.05$

Et/Eto $=$ Perbandingan evapotranspirasi actual (Et) dengan Evapotraspirasi potensial $\mathrm{Rn}=$ Jumlah hari hujan bulanan

\section{c. Indeks Erodibilitas (K)}

Erodibilitas tanah adalah kemudahan/kepekaan tanah untuk tererosi. Dimana masingmasing tanah mempunyai ketahanan yang berbeda terhadap erosi. Jadi tanah yang memiliki nilai erodibilitas $(\mathrm{K})$ yang tinggi dengan curah hujan yang sama, akan lebih mudah tererosi dari pada tanah dengan tingkat erodibilitas (K) rendah. Nilai erodibilitas yang diperoleh pada tabel berdasarkan penelitian terhadap berbagai jenis tanah ke tekstur tanah tertera pada tabel dibawah ini : 
Volume $1 \quad$ Nomor 2 Oktober 2016

Tabel 1. Tabel Konversi Jenis Tanah Ke Tekstur Tanah

\begin{tabular}{|c|c|c|}
\hline No & Jenis Tanah & Tekstur Tanah \\
\hline 1 & Latosol & $\begin{array}{c}\text { Halus } \\
\text { (kandungan liat }> \\
60 \%)\end{array}$ \\
\hline 2 & Andosol & Sedang \\
\hline 3 & $\begin{array}{c}\text { Regosol } \\
\text { (Grumusol) }\end{array}$ & $\begin{array}{c}\text { Halus } \\
\text { (kandungan liat }> \\
30 \% \text { ) }\end{array}$ \\
\hline 4 & Aluvial & Halus - kasar \\
\hline 5 & Glei Humus & Halus \\
\hline
\end{tabular}

Sumber : Hardjowigeno, 1995

Tabel 2. Tabel Nilai MS, $\rho b$ dan $K$ pada berbagai macam tekstur tanah

\begin{tabular}{|l|c|c|c|c|}
\hline Tekstur Tanah & $\begin{array}{c}\text { MS } \\
\mathbf{\%} \\
\mathbf{w} / \mathbf{~}\end{array}$ & $\begin{array}{c}\mathbf{\rho b} \\
\mathbf{M g}\end{array}$ & $\begin{array}{c}\mathbf{K} \\
\mathbf{~ m ~ j}^{-\mathbf{1}}\end{array}$ & $\begin{array}{c}\text { RD } \\
\mathbf{~ m}\end{array}$ \\
\hline \hline Liat (clay) & 45 & 1.1 & 0.02 & $*)$ \\
\hline $\begin{array}{l}\text { Lempung } \\
\text { berliat }\end{array}$ & 40 & 1.3 & 0.4 & \\
\hline Liat berdebu & 30 & - & - & \\
\hline $\begin{array}{l}\text { Lempung } \\
\text { berpasir }\end{array}$ & 28 & 1.2 & 0.3 & \\
\hline $\begin{array}{l}\text { Lempung } \\
\text { berdebu }\end{array}$ & 25 & 1.3 & - & \\
\hline Lempung & 20 & 1.3 & - & \\
\hline Pasir halus & 15 & 1.4 & 0.2 & \\
\hline Pasir halus & 8 & 1.5 & 0.7 & \\
\hline
\end{tabular}

Sumber : Utomo, 1994

Keterangan :

*) Nilai RD dapat digunakan $0.05 \mathrm{~m}$ untuk rumput dan padi-padian;

Tabel 3. Klas Tekstur Untuk rupa dan Seri Tanah

\begin{tabular}{|c|l|l|}
\hline No & $\begin{array}{c}\text { Kelas Tekstur } \\
\text { Rupa }\end{array}$ & $\begin{array}{c}\text { Kelas Tekstur } \\
\text { Seri }\end{array}$ \\
\hline \hline 1 & Kasar & $\begin{array}{l}\text { Pasir, pasir } \\
\text { berlempung }\end{array}$ \\
\hline 2 & Agak Kasar & Lempung berpasir \\
\hline 3 & Sedang & $\begin{array}{l}\text { Lempung, } \\
\text { lempung berdebu, } \\
\text { debu }\end{array}$ \\
\hline 4 & & $\begin{array}{l}\text { Lempung liat } \\
\text { berpasir, lempung } \\
\text { liat, lempung liat } \\
\text { berdebu }\end{array}$ \\
\hline 5 & Halus & $\begin{array}{l}\text { Liat berpasir, liat } \\
\text { berdebu, liat }\end{array}$ \\
\hline
\end{tabular}

Sumber : Hardjowigeno, 1995

Tabel 4. Nilai $\mathrm{C}$ dan Et/Eo beberapa macam tanaman untuk model MMF

\begin{tabular}{|l|c|c|c|}
\hline Tanaman & $\begin{array}{c}\mathbf{A} \\
(\mathbf{\%})\end{array}$ & $\mathbf{C}$ & $\mathbf{E t} / \mathbf{E o}$ \\
\hline Padi Sawah & - & 0.2 & 1.35 \\
\hline Wheat & 43 & 0.2 & 0.6 \\
\hline Jagung & 25 & 0.2 & 0.70 \\
\hline Cassava & - & $0.4-$ & $0.67-$ \\
\hline Kentang & 12 & 0.3 & 0.62 \\
\hline
\end{tabular}




\begin{tabular}{|l|c|c|c|}
\hline Beans & $20-$ & $0.2-$ & $0.62-$ \\
Kacang & 25 & 0.4 & 0.69 \\
Tanah & 25 & $0.2-$ & $0.50-$ \\
\hline Teh & & $0.1-$ & $0.85-$ \\
\hline & - & 0.3 & 1.00 \\
Karet & $20-$ & & \\
\hline & 30 & 0.2 & 0.9 \\
Kelapa sawit & 30 & 0.30 & 1.2 \\
\hline Rumput & $25-$ & $0.01-$ & $0.80-$ \\
prairie & 40 & 0.10 & 0.95 \\
\hline & $25-$ & $0.011-$ & $0.90-$ \\
Hutan & 30 & 0.002 & 1.00 \\
\hline Tanah bero & 0 & 1 & 0.05 \\
\hline
\end{tabular}

Sumber : Hardjowigeno, 1995

\section{d. Faktor Pengelolaan Tanaman $(C)$}

Indeks pengelolaan tanaman (C) dapat diartikan sebagai rasio tanah yang tererosi pada suatu jenis pengelolaan tanaman pada sebidang lahan terhadap tanah yang tererosi pada lahan yang sama tanpa ada tanaman. Nilai $C$ untuk suatu jenis pengelolaan tanaman tergantung dari jenis, kombinasi, kerapatan, panen dan rotasi tanaman. Vegetasi yang tumbuh pada suatu lahan dapat bervariasi sesuai dengan pola tata tanam dan masa pertumbuhan tanaman, sehingga SWAT merubah $C_{U S L E}$ dengan persamaan sebagai berikut:

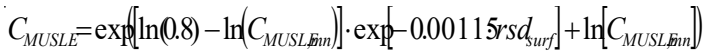
dengan :

$C_{M U S L E, m n}=$ nilai minimum faktor pengelolaan tanaman

$r s d_{\text {surf }}=$ jumlah residue (mulsa, sisa-sisa tanaman) di permukaan tanah $(\mathrm{kg} /$ ha)
Nilai minimum faktor pengelolaan tanaman dapat dihitung dari nilai rata-rata tahunan faktor $C$ dengan menggunakan persamaan (Arnold and Williams, 1995) :

$C_{\text {MUSLFinn }}=1.463 \ln \left[C_{\text {USLEaa }}\right]+0.103$

dengan :

$C_{\text {MUSLE }, a a}=$ nilai rata-rata tahunan faktor $C$

Pada Tabel 2.4. ditunjukkan beberapa angka $C$ yang diperoleh dari hasil penelitian Pusat Penelitian Tanah, Bogor. Pada penelitian tersebut, pengelolaan tanaman, pemilihan bibit, pengolahan tanah, waktu tanam, dan pemeliharaan semuanya sesuai dengan anjuran Dinas Pertanian.

\section{e. Faktor Pengelolaan Tanaman dan Konservasi Tanah $(P)$}

Faktor tindakan konservasi adalah nisbah antara besarnya erosi dari lahan dengan suatu tindakan konservasi tertentu terhadap besarnya erosi pada lahan tanpa tindakan konservasi (Suripin, $2002: 80$ ). Efektifitas tindakan konservasi dalam mengendalikan erosi tergantung pada panjang dan kemiringan lereng. Morgan (1988) dalam Suripin (2002) menyatakan bahwa pencangkulan dan penanaman searah kontur dapat mengurangi erosi tanah pada lahan yang miring, sampai $50 \%$ dibandingkan dengan penanaman ke arah atas-bawah. Nilai faktor $P$, dapat dilihat pada Tabel 5 berikut.

Tabel 5. Nilai $C$ untuk berbagai jenis tanaman dan pengelolaan tanaman

\begin{tabular}{|l|c|}
\hline \multicolumn{1}{|c|}{ Jenis tanaman/tataguna lahan } & Nilai \\
\hline Tanaman rumput (Brachiaria sp.) & 0,290 \\
\hline Tanaman kacang jogo & 0,161 \\
\hline Tanaman Gandum & 0,242 \\
\hline Tanaman ubi kayu & 0,363 \\
\hline Tanaman kedelai & 0,399 \\
\hline
\end{tabular}




\begin{tabular}{|l|c|}
\hline Tanaman serai wangi & 0,434 \\
\hline Tanaman padi lahan kering & 0,560 \\
\hline Tanaman padi lahan basah & 0,010 \\
\hline Tanaman jagung & 0,637 \\
\hline Tanaman jahe, cabe & 0,900 \\
\hline Pola tanam berurutan & 0,398 \\
\hline Pola tanam tumpang gilir + mulsa sisa & 0,357 \\
tanaman & \\
\hline Kebun campuran & 0,200 \\
\hline Ladang berpindah & 0,400 \\
\hline Tanah kosong diolah & 1,000 \\
\hline Tanah kosong tidak diolah & 0,950 \\
\hline Hutan tidak terganggu & 0,001 \\
\hline Semak tidak terganggu & 0,010 \\
\hline Alang-alang permanen & 0,020 \\
\hline Sengon disertai semak & 0,012 \\
\hline Sengon tidak disertai semak dan tanpa & 1,000 \\
\hline seresah & 0,320 \\
\hline Pohon tanpa semak & \\
\hline
\end{tabular}

Sumber : Abdurachman dkk., 1984

\section{f. Faktor Topografi Panjang lereng $(L)$ dan Kemiringan Lereng $(S)$}

Faktor indeks topografi $L$ dan $S$, masingmasing mewakili pengaruh panjang dan kemiringan lereng terhadap besarnya erosi. Panjang lereng mengacu pada aliran air permukaan, yaitu lokasi berlangsungnya erosi dan kemungkinan terjadinya deposisi sedimen. Pada umumnya, kemiringan lereng diperlakukan sebagai faktor yang seragam. Besarnya nilai $L S$ (faktor topografi) dihitung dengan menggunakan rumus (Anonim, $2002: 222$ ).

$$
\begin{aligned}
\text { dengan : } & \\
L_{\text {hill }} & =\text { panjang lereng }(\mathrm{m}) \\
m & =\text { syarat eksponensial } \\
\alpha_{\text {hill }} & =\text { sudut lereng }
\end{aligned}
$$$$
L S_{\text {MUSLE }}=\left(\frac{L_{\text {hill }}}{22.1}\right)^{m} \cdot\left(65.41 \cdot \sin ^{2}\left(\alpha_{\text {hill }}\right)+4.56 \cdot \sin \alpha_{\text {hill }}+0.065\right)
$$

Syarat eksponensial $m$ dihitung dengan :

$$
m=0.6 \cdot(1-\exp [-35.835 \cdot \operatorname{slp}])
$$

dengan :

slp = kemiringan lereng HRU (Hydrologic Response Unit) $=\tan \alpha_{\text {hill }}$

\section{g. Faktor Pecahan Batuan Kasar (Coarse Fragment Factor)}

Faktor pecahan batuan kasar ini dihitung dengan persamaan sebagai berikut (Anonim, 2002:220) :

CFRG $=\exp (-0,053$. rock $)$

dengan :

rock = persentase batuan pada lapisan tanah.

\section{h. Faktor Panjang Lereng (L) dan Kemi ringan Lereng (S)}

Faktor panjang lereng (L) dan kemiringan lereng (S) mempengaruhi besarnya erosi yang terjadi. Sifat lereng yang mempengaruhi energi penyebab erosi adalah :

1. Kemiringan lereng

2. Panjang lereng

3. Bentuk lereng

Kemiringan mempengaruhi kecepatan dan volume limpasan permukaan. Faktor panjang lereng dihitung dengan persamaan (Anonim, 1998 : 49):

$$
\mathrm{L}=\sqrt{\frac{L o}{22}}
$$

$$
\text { dengan : }
$$

$\mathrm{L} \quad=$ nilai faktor panjang lereng

Lo = panjang lereng $(\mathrm{m})$

Hasil perhitungan nilai faktor panjang lereng dengan rumus tersebut dapat dilihat pada tabel : 
Tabel 6. Nilai Faktor Panjang Lereng (L)

\begin{tabular}{|c|c|}
\hline $\begin{array}{c}\text { Rata-rata Panjang } \\
\text { Lereng }(\mathrm{m})\end{array}$ & Nilai $\mathrm{L}$ \\
\hline 50 & 1,5 \\
\hline 75 & 1,8 \\
\hline 150 & 2,7 \\
\hline 300 & 3,7 \\
\hline
\end{tabular}

Sumber: Dirjen Reboisasi dan Rehabilitasi Lahan, 1998

Nilai faktor kemiringan lereng (S) dapat dihitung dengan cara empiris dan estimasi, yang dinyatakan dalam bentuk persamaan berikut (Anonim, $1998: 50)$ :

$$
\mathrm{S}=(\mathrm{s} / 9)^{1,4}
$$

dengan :

$\mathrm{S}=$ kemiringan lereng $(\%)$

Berdasarkan klas kemiringan lereng, besarnya nilai faktor $\mathrm{S}$ dapat dihitung dan dimuat pada Tabel 7 berikut :

Tabel 7. Nilai Faktor Kemiringan Lereng (S)

\begin{tabular}{|c|c|c|}
\hline $\begin{array}{c}\text { Klas } \\
\text { Lereng }\end{array}$ & Kemiringan (\%) & $\begin{array}{c}\text { Rata-rata } \\
\text { Nilai S }\end{array}$ \\
\hline I & $0-3$ & 0,1 \\
\hline II & $3-8$ & 0,5 \\
\hline III & $8-15$ & 1,4 \\
\hline IV & $15-25$ & 3,1 \\
\hline V & $25-40$ & 6,1 \\
\hline VI & $40-65$ & 11,9 \\
\hline
\end{tabular}

Sumber: Dirjen Reboisasi dan Rehabilitasi Lahan, 1998

\section{i. Faktor Pengelolaan Tanaman dan Konservasi Tanah (CP)}

Indeks pengelolaan tanaman (C) dapat diartikan sebagai rasio tanah yang tererosi pada suatu jenis pengelolaan tanaman pada sebidang lahan terhadap tanah yang tererosi pada lahan yang sama tanpa ada tanaman. Indeks pengolahan lahan $(\mathrm{P})$ adalah rasio tanah yang tererosi pada suatu jenis pengelolaan lahan terhadap tanah yang tererosi pada lahan yang sama tanpa praktek pengelolaan lahan atau konservasi tanah apapun, seperti misalnya teras, rorak, pengelolaan tanah dan sebagainya. Besaran nilai CP ditentukan berdasarkan keanekaragaman bentuk tata guna lahan dilapangan.

Tabel 8. Nilai Faktor CP Berbagai Jenis Penggunaan Lahan

\begin{tabular}{|c|c|c|}
\hline No & Jenis Tanaman & Nilai CP \\
\hline 1 & Lahan Tanpa Tanaman & 1.00 \\
\hline 2 & $\begin{array}{ll}\text { Hutan } & \\
\text { - } & \text { Tak terganggu } \\
- & \text { Tanpa tanaman bawah } \\
- & \text { Tanpa tanaman bawah } \\
& \text { dan serasah }\end{array}$ & $\begin{array}{l}0.001 \\
0.030 \\
0.500\end{array}$ \\
\hline 3 & 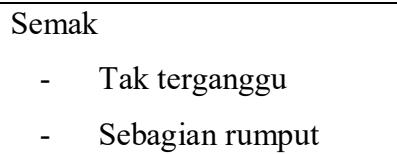 & $\begin{array}{c}0.01 \\
0.100\end{array}$ \\
\hline 4 & $\begin{array}{ll}\text { Kebun } & \\
- & \text { Campuran asli } \\
- & \text { Kebun } \\
- & \text { Pekarangan }\end{array}$ & $\begin{array}{l}0.020 \\
0.070 \\
0.200\end{array}$ \\
\hline 5 & $\begin{array}{l}\text { Perkebunan } \\
\text { - } \quad \text { Penutupan tanah } \\
\text { sempurna } \\
\text { - } \quad \text { Ditumbuhi alang- } \\
\text { alang } \\
\text { - } \quad \text { Perkarangan alang- } \\
\text { alang setahun sekali } \\
\text { - Jenis serai (Citronella } \\
\text { grass) } \\
\text { - Savana dan padang } \\
\text { rumput } \\
\text { - }\end{array}$ & 0.020 \\
\hline
\end{tabular}




\section{JUTEKS Jurnal Teknik Sipil Volume 1 Nomor 2 Oktober 2016}

\begin{tabular}{|c|c|c|}
\hline 6 & 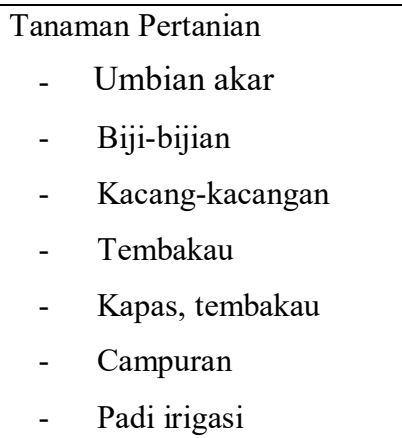 & $\begin{array}{c}0.630 \\
0.510 \\
0.360 \\
0.580 \\
0.500 \\
0.430 \\
0.20\end{array}$ \\
\hline 7 & $\begin{array}{l}\text { Peladangan } \\
\text { - } \quad \text { Satu tahun tanam, satu } \\
\text { tahun bera } \\
\text { - } \quad \text { Satu tahun tanam, dua } \\
\text { tahun bera }\end{array}$ & 0.280 \\
\hline 8 & 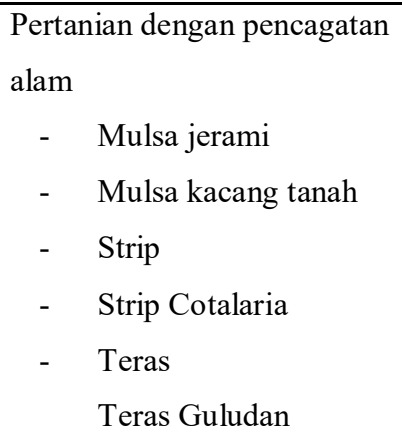 & $\begin{array}{c}0.06-0.20 \\
0.20-0.40 \\
0.10-0.30 \\
0.640 \\
0.040 \\
0.140\end{array}$ \\
\hline
\end{tabular}

Sumber : Utomo, 1994 :151

\section{j. Pendugaan Kekritisan Lahan}

Lahan kritis didefinisikan sebagai lahan yang telah mengalami kerusakan sehingga kehilangan atau berkurang fungsinya sampai pada batas yang ditentukan atau diharapkan. Metode penilaian kriteria penetapan lahan kritis mengacu pada definisi lahan kritis hasil lokakarya Direktorat Rehabilitasi dan Konservasi Tanah pada tanggal 17 Juni 1997 dan diskusi tersebut adalah Kriteria Penetapan Lahan Kritis yang tertuang dalam Surat Edaran Nomor : 118/V/RKT-3/1998, tanggal 17 Februari 1998. Tingkat kekritisan lahan suatu wilayah ditentukan oleh beberapa faktor, yaitu:

- Faktor tutupan lahan (Landcover).

- Faktor topografi (lereng) diperoleh dari peta rupa bumi Indonesia.

- Faktor erosi, dianalisa dari peta jenis dan kemampuan tanah.

- Faktor manajemen pengolahan lahan, dianalisa dari data citra satelit Landsat 7 ETM, dan SPOT HRV.

- Faktor curah hujan yang dianalisis dari data curah hujan yang ada.

Dari data yang terkumpul, kemudian dianalisa dengan metode skoring untuk masingmasing kriteria data pendukung sesuai dengan metode yang berlaku. Kriteria skoringpembobotan dapat dilihat pada Tabel 2.9. Agar lebih mudah, cepat, dan akurat dalam pelaksanaan analisa ini maka akan digunakan teknologi Sistem Informasi Geografis. Dengan membuat layer-layer untuk setiap peta yang diperlukan dalam analisa Indeks Bahaya Erosi (IBE) untuk menentukan tingkat kekritisan lahan dan mengoverlaykan layer-layer tersebut, maka dengan mudah akan diperoleh data skor untuk masing-masing unit lahan. Dengan mengelompokkan nilai skor setiap unit lahan sesuai dengan kriteria pada Tabel 9 maka dapat ditentukan tingkat kekritisan lahannya. 
Sutirto $^{1}$, Johannis ${ }^{2}$ Falo $^{3}$, Analisis Penempatan Dan Desain Bangunan Pengendali Sedimen Guna

Penanganan Laju Erosi Di DAS Oesapa Besar Kupang Provinsi Nusa Tenggara Timur

Tabel 9. Kriteria Penentuan Tingkat Kekritisan Lahan

\begin{tabular}{|c|c|c|c|c|}
\hline No & Kriteria & Bobot & Besaran/Deskripsi & Skor \\
\hline 1 & $\begin{array}{l}\text { Penutupan } \\
\text { Lahan } \\
{[50]}\end{array}$ & $\begin{array}{l}\text { 1. Sangat Baik } \\
\text { 2. Baik } \\
\text { 3. Sedang } \\
\text { 4. Buruk } \\
\text { 5. Sangat Buruk }\end{array}$ & $\begin{array}{c}>80 \% \\
61-80 \% \\
41-60 \% \\
21-40 \% \\
<20 \% \\
\end{array}$ & $\begin{array}{l}5 \\
4 \\
3 \\
2 \\
1 \\
\end{array}$ \\
\hline 2 & $\begin{array}{l}\text { Lereng } \\
{[20]}\end{array}$ & $\begin{array}{l}\text { 1. Datar } \\
\text { 2. Landai } \\
\text { 3. Agak Curam } \\
\text { 4. Curam } \\
\text { 5. Sangat Curam }\end{array}$ & $\begin{array}{c}<8 \% \\
8-15 \% \\
16-25 \% \\
26-40 \% \\
>40 \% \\
\end{array}$ & $\begin{array}{l}5 \\
4 \\
3 \\
2 \\
1 \\
\end{array}$ \\
\hline \multirow[t]{4}{*}{3} & \multirow[t]{4}{*}{$\begin{array}{l}\text { Erosi } \\
{[20]}\end{array}$} & 1. Ringan & $\begin{array}{l}\text { a. Tanah dalam : kurang dari } 25 \% \\
\text { lapisan tanah atas hilang atau } \\
\text { erosi alur pada jarak } 20-50 \mathrm{~m} \text {. } \\
\text { b. Tanah dangkal : kurang dari } \\
25 \% \text { lapisan tanah atas hilang } \\
\text { atau erosi alur pada jarak }>50 \mathrm{~m} \text {. }\end{array}$ & 5 \\
\hline & & 2. Sedang & $\begin{array}{l}\text { a. Tanah dalam : } 25-75 \% \\
\text { lapisan tanah atas hilang atau } \\
\text { erosi alur pada jarak }<20 \mathrm{~m} \text {. } \\
\text { b. Tanah dangkal: kurang dari } \\
25-50 \% \text { lapisan tanah atas } \\
\text { hilang atau erosi alur pada jarak } \\
20-50 \mathrm{~m} \text {. }\end{array}$ & 4 \\
\hline & & 3. Berat & $\begin{array}{l}\text { a. Tanah dalam : lebih dari } 75 \% \\
\text { lapisan tanah atas hilang atau } \\
\text { erosi parit pada jarak } 20-50 \mathrm{~m} \text {. } \\
\text { b. Tanah dangkal : } 20-75 \% \\
\text { lapisan tanah atas hilang. }\end{array}$ & 3 \\
\hline & & 4. Sangat Berat & $\begin{array}{l}\text { a. Tanah dalam : semua tanah atas } \\
\text { hilang }>25 \% \text { lapisan tanah } \\
\text { bawah atau erosi parit dengan } \\
\text { kedalaman sedang pada jarak } \\
<20 \mathrm{~m} \text {. } \\
\text { b. Tanah dangkal : kurang dari } \\
75 \% \text { lapisan tanah atas hilang } \\
\text { dan sebagian tanah bawah telah } \\
\text { tererosi. }\end{array}$ & 2 \\
\hline 4 & $\begin{array}{l}\text { Manajemen } \\
{[10]}\end{array}$ & $\begin{array}{l}\text { 1. Baik } \\
\text { 2. Sedang } \\
\text { 3. Buruk }\end{array}$ & $\begin{array}{l}\text { Lengkap } \\
\text { Tidak Lengkap } \\
\text { Tidak Ada }\end{array}$ & $\begin{array}{l}5 \\
3 \\
1\end{array}$ \\
\hline
\end{tabular}

Sumber : Keputusan Dirjen Reboisasi dan Rehabilitasi Lahan, 1998 


\section{JUTEKS Jurnal Teknik Sipil Volume 1 Nomor 2 Oktober 2016}

Tabel 10. Tingkat Kekritisan Lahan

\begin{tabular}{|c|l|c|}
\hline No & Tingkat Kekritisan Lahan & Besaran Nilai \\
\hline 1 & Sangat Kritis & $120-180$ \\
\hline 2 & Kritis & $181-270$ \\
\hline 3 & Agak Kritis & $271-360$ \\
\hline 4 & Potensial Kritis & $361-450$ \\
\hline 5 & Tidak Kritis & $451-500$ \\
\hline
\end{tabular}

Sumber: Keputusan Dirjen Reboisasi dan Rehabilitasi Lahan, 1998

\section{k. Batas Laju Erosi Yang Diperbolehkan}

Penetapan batas tertinggi laju erosi yang masih dapat diperbolehkan atau ditoleransikan adalah perlu, karena tidaklah mungkin menekan laju erosi menjadi nol dari tanah-tanah yang diusahakan untuk pertanian terutama pada tanah-tanah yang berlereng.

Menurut Arsyad, dengan menggunakan nisbah nilai untuk berbagai sifat dan stratum tanah, maka untuk tanah di Indonesia disarankan nilai erosi yang diperbolehkan (T), disajikan dalam tabel berikut :

Tabel 11. Pedoman Penetapan Nilai T untuk Tanah-Tanah di Indonesia

\begin{tabular}{|c|l|c|}
\hline No. & \multicolumn{1}{|c|}{ Sifat Tanah dan SubStratum } & Nilai T \\
$(\mathrm{mm} / \mathrm{th})$
\end{tabular}

\begin{tabular}{|l|l|c|}
\hline 5 & $\begin{array}{l}\text { Tanah yang dalam dengan } \\
\text { lapisan bawah yang kedap air } \\
\text { di atas substrata yang telah } \\
\text { melapuk }\end{array}$ & 1,4 \\
\hline 6 & $\begin{array}{l}\text { Tanah yang dalam dengan } \\
\text { lapisan bawah berpermeabilitas } \\
\text { lambat, di atas substrata yang } \\
\text { telah melapuk }\end{array}$ & 1,6 \\
\hline 7 & $\begin{array}{l}\text { Tanah yang dalam dengan } \\
\text { lapisan bawah berpermeabilitas } \\
\text { sedang, di atas substrata yang } \\
\text { telah melapuk }\end{array}$ & 2,0 \\
\hline 8 & $\begin{array}{l}\text { Tanah yang dalam dengan } \\
\text { lapisan bawah yang permeabel, } \\
\text { di atas substrata yang telah } \\
\text { melapuk }\end{array}$ & 2,5 \\
\hline
\end{tabular}

Sumber : Arsyad, $2000: 244$

\section{Indeks Bahaya Erosi}

Besarnya nilai bahaya erosi dinyatakan dalam Indeks Bahaya Erosi, yang didefinisikan sebagai berikut (Hammer 1981 dalam Arsyad $2000: 274)$ :

Indeks Bahaya Erosi =

$$
\frac{\text { ErosiPotensial(ton / ha / tahun })}{T(\text { ton / ha / tahun })}
$$

Dengan $T$ adalah besarnya erosi yang masih dapat dibiarkan. Indeks bahaya erosi dapat ditentukan Tabel 12.

Tabel 12. Klasifikasi Indeks Bahaya Erosi

\begin{tabular}{|c|c|}
\hline $\begin{array}{c}\text { Nilai Indeks } \\
\text { Bahaya Erosi }\end{array}$ & Harkat \\
\hline$<1,0$ & Rendah \\
\hline $1,01-4,0$ & Sedang \\
\hline $4,01-10,0$ & Tinggi \\
\hline$>10,01$ & Sangat Tinggi \\
\hline
\end{tabular}

Sumber : Arsyad, $2000: 275$ 


\section{m. Bangunan Pengendali Erosi}

Menurut Utomo, Wani Hadi. 1994 : 78, Usaha untuk memperlambat proses sedimentasi antara lain dengan mengadakan pekerjaan teknik sipil untuk mengendalikan gerakannya menuju bagian sungai dibagian hilirnya. Adapun pekerjaannya adalah berupa pembangunan bendungan penahan ( check dam, kantong lahar, bendung pengatur, bending konsolidasi serta pekerjaan normalisasi alur sungai (chennel work) dan pekerjaan pengendalian erosi di lereng-lereng pegunungan ( hill side work).

Penentuan letak / lokasi kedudukan check dam berdasarkan pada tujuan pembangunannya adalah sebagai berikut :

1). Untuk tujuan pencegahan terjadinya sedimentasi yang mendadak dengan jumlah sangat besar yang timbul akibat terjadinya tanah longsor, sedimen luruh, banjir lahar dan lainlain, maka letak/lokasi check dam direnca-nakan pada lokasi sebelah hilir dan daerah sumber sedimen yang labil tersebut, yaitu pada alur sungai yang dalam, agar dasar sungai naik dengan adanya check dam tersebut. Selain beberapa hal tersebut diatas, dasar perencanaan untuk penentuan titik dasar (basic point) check dam adalah sebagai berikut : 2). Prinsip Bangunan Check Dam Bangunan ini direncanakan pada daerah erosi vertical dari alur sungai. Fungsi check dam adalah untuk menahan material dan mencegah erosi. Dalam kasus erosi vertical sepanjang alur sungai, bangunan check dam digunakan untuk membuang sedimen yang merusak daerah sasaran; 3). Titik Dasar ( Basic Point) Perencanaan Check Dam. Titik dasar untuk perencanaan check dam adalah suatu titik batas untuk menentukan jumlah sedimen yang dibicarakan dan yang diijinkan; 4). Estimasi Sedimen untuk Perencanaan Check Dam; 5). Jumlah sedimen yang dihasilkan di daerah sasaran harus diestimasi sebagai jumlah mate- rial / sedimentasi. Jumlah estimasi tersebut akan menjadi patokan mendasar dari peren-canaan check dam; 6). Jumlah Aliran Sedimen yang diijinkan; 7). Jumlah material sedimen yang diijinkan didefinisikan sebagai sejumlah materal yang mengalir menuju hilir sungai tanpa membuat kerusakan dan alur sungai tetap terjaga dalam kondisi yang aman dan stabil: 8). Jumlah Kelebihan Aliran Sedimen; 9). Jumlah kelebihan aliran sedimen pada suatu titik tertentu pada perencanaan check dam ditentukan sebagai jumlah yang harus dikendalikan di sebelah hulu titik tersebut. Hal ini dimaksudkan agar sedimen yang melewati suatu titik dasar adalah jumlah material yang diijinkan.

\section{n. Tinggi Bangunan Utama}

Tinggi bangunan utama sangat berpengaruh terhadap kapasitas tampungan sedimen. Dalam menentukan tinggi check dam, kemiringan dasar sungai yang akan dicapai ( kemiringan seimbang) setelah adanya bangunan tersebut harus diketahui lebih dahulu. Kemiringan dasar sungai yang akan tercapai berdasarkan pengamatan di lapangan biasanya berkisar $1 / 2$ - 2/3 dari kemiringan dasar sungai asli. Pada bangunan pengendali sedimen di daerah pegunungan seringkali pondasi ditempatkan pada posisi mengapung yaitu di atas lapisan pasir, kerikil dan boulder yang menjadi satu, maka tinggi bangunan tidak diperbolehkan melebihi 15 meter.

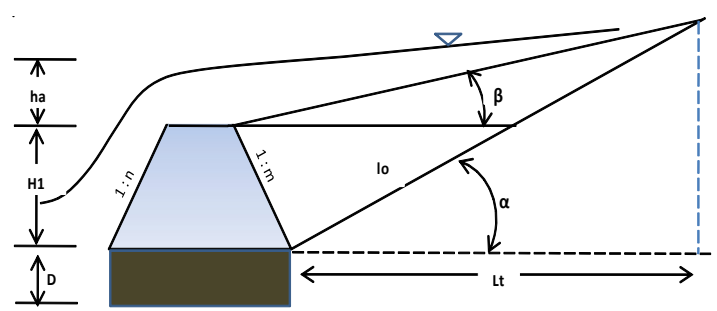

Gambar 1. Penentuan Tinggi Bangunan Utama

Sumber : Utomo, Wani Hadi, 1994 : 101 
Rumus yang sering dipergunakan dalam menentukan tinggi bangunan utama adalah sebagai berikut :

$$
H=L_{1} \cdot(\operatorname{tg} \alpha-\operatorname{tg} \beta)
$$

Dimana :

$\mathrm{H}=$ Tinggi bangunan utama $(\mathrm{m})$

$\mathrm{L} \quad=$ Panjang aliran sungai $(\mathrm{m})$

$\operatorname{tg} \alpha=$ Kemiringan dasar sungai asli ( 1o)

$\operatorname{tg} \beta=$ Kemiringan dasar sungai rencana (1/22/3) lo

\section{METODE PENELITIAN}

\section{a. Lokasi Studi}

Adapun lokasi penelitian yang termasuk dalam DAS Oesapa Besar meliputi Kecamatan: - Di bagian hilir Kecamatan Kelapa Lima dan Kecamatan Oebobo Kota Kupang.

- Di bagian tengah Kecamatan Maulafa Kota Kupang dan di Kecamatan Taebenu Kabupaten Kupang.

- Di bagian hulu Kecamatan Taebenu dan Kecamatan Nekmese Kabupaten Kupang.

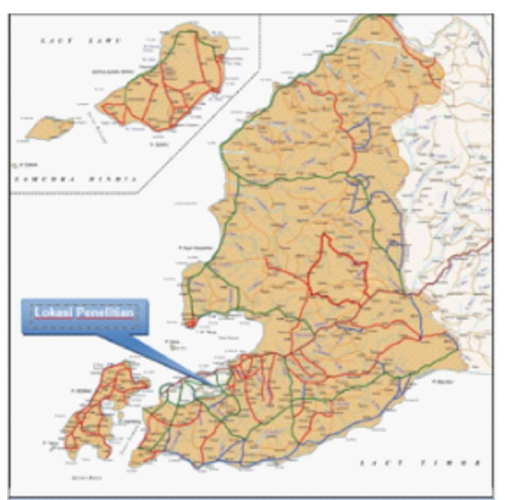

Gambar 2. Lokasi Penelitian

\section{b. Langkah Penelitian}

Adapun langkah penelitian ini dapat di lihat pada diagram alir di bawah ini :

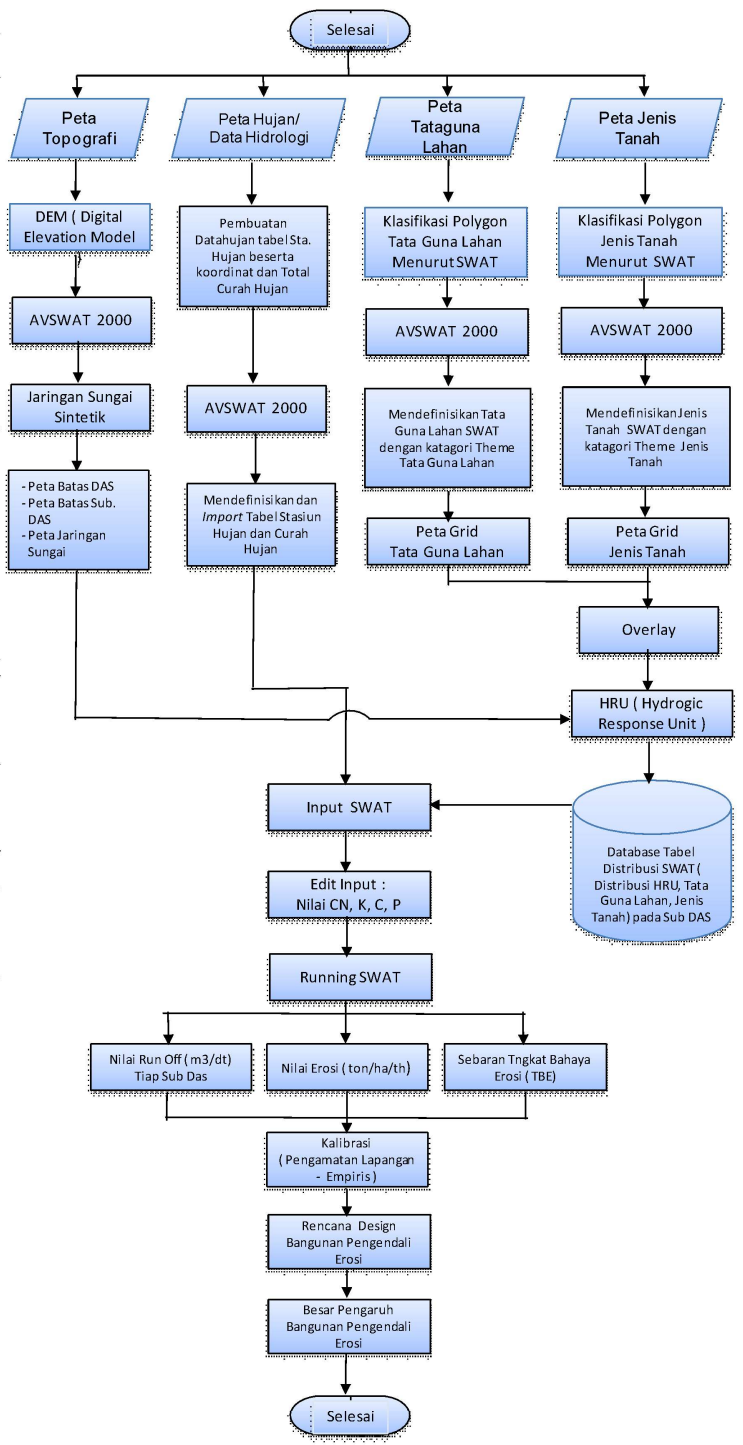

Gambar 3. Diagram Alir Peneltian

\section{HASIL DAN PEMBAHASAN}

\section{a. Debit Limpasan di DAS Oesapa Besar}

Penentuan besarnya debit limpasan metode rasional modifikasi dengan cara analisa spasial tumpang susun (overlay) dengan menggunakan perangkat lunak. Data-data yang digunakan adalah peta DAS Oesapa Besar (Koef CS dan I), peta penggunaan lahan (Koefisien C). Rumus yang digunakan berdasarkan persamaan debit limpasan rasional modifikasi didapat hasil perhitungan : 
$\mathrm{Q}_{1,01 \text { th }}=33,59874 \mathrm{~m}^{3} /$ detik, $\mathrm{Q}_{5 \text { th }}=65,09085$ $\mathrm{m}^{3} /$ detik, $\mathrm{Q}_{10 \text { th }}=86,58821 \mathrm{~m}^{3} / \operatorname{detik}, \mathrm{Q}_{15 \mathrm{th}}=$ $101,54622 \mathrm{~m}^{3} /$ detik, $Q_{20 \mathrm{th}}=121,31350 \mathrm{~m}^{3} /$ detik

b. Perhitungan Indeks Erosivitas Limpasan Permukaan (Rw)

Hasil perhitungan Rw disajikan pada Tabel di bawah ini :

Tabel 13. Rekapitulasi Erosivitas Limpasan Permukaan

(Rw) DAS Oesapa Besar

\begin{tabular}{|c|c|c|c|}
\hline No & Sub-sub DAS & $\begin{array}{l}\text { Luas } \\
(\mathrm{Ha})\end{array}$ & $\begin{array}{c}\mathrm{Rw} \\
\left(\mathrm{m}^{3} / \mathrm{jam}\right)\end{array}$ \\
\hline 1 & 2 & & \\
\hline 1 & 1 & 48.750 & 0.186 \\
\hline 2 & 2 & 30.750 & 0.159 \\
\hline 3 & 3 & 47.500 & 0.140 \\
\hline 4 & 4 & 2.250 & 0.000 \\
\hline 5 & 5 & 67.000 & 0.116 \\
\hline 6 & 6 & 56.000 & 0.094 \\
\hline 7 & 7 & $\begin{array}{r}85.000 \\
\end{array}$ & 0.162 \\
\hline 8 & 8 & $\begin{array}{l}183.500 \\
171.750\end{array}$ & 0.279 \\
\hline $\begin{array}{c}9 \\
10\end{array}$ & $\begin{array}{r}9 \\
10\end{array}$ & $\begin{array}{r}171.750 \\
59.250\end{array}$ & $\begin{array}{l}0.197 \\
0.147\end{array}$ \\
\hline 11 & 11 & $\begin{array}{r}5.750 \\
5.200\end{array}$ & 0.041 \\
\hline 12 & 12 & 35.000 & 0.123 \\
\hline 13 & 13 & 2.500 & 0.024 \\
\hline 14 & 14 & 13.500 & 0.077 \\
\hline 15 & 15 & 55.000 & 0.200 \\
\hline 16 & 16 & 146.250 & 0.175 \\
\hline 17 & 17 & 134.750 & 0.154 \\
\hline 18 & 18 & 97.500 & 0.182 \\
\hline 19 & 19 & 35.750 & 0.092 \\
\hline 20 & 20 & 35.750 & 0.098 \\
\hline 21 & 21 & 4.500 & 0.038 \\
\hline 22 & 22 & $\begin{array}{r}99.000 \\
\end{array}$ & 0.168 \\
\hline 23 & 23 & 332.750 & 0.217 \\
\hline 24 & $\begin{array}{l}24 \\
25\end{array}$ & $\begin{array}{l}43.500 \\
35.500\end{array}$ & $\begin{array}{l}0.166 \\
0.092\end{array}$ \\
\hline 26 & 26 & 151.250 & 0.168 \\
\hline 27 & 27 & 51.750 & 0.099 \\
\hline 28 & 28 & 4.250 & 0.041 \\
\hline 29 & 29 & 110.000 & 0.181 \\
\hline 30 & 30 & 30.000 & 0.110 \\
\hline 31 & 31 & 65.000 & 0.157 \\
\hline 32 & 32 & 28.500 & 0.135 \\
\hline 33 & 33 & 45.250 & 0.142 \\
\hline 34 & 34 & 39.250 & 0.133 \\
\hline 35 & 35 & 26.250 & 0.080 \\
\hline 36 & 36 & 27.750 & 0.113 \\
\hline 37 & 37 & 47.250 & 0.136 \\
\hline 38 & 38 & 44.500 & 0.162 \\
\hline 39 & 39 & 105.250 & 0.165 \\
\hline 40 & 40 & 31.000 & 0.104 \\
\hline 41 & 41 & 79.750 & 0.125 \\
\hline 42 & 42 & 37.000 & 0.105 \\
\hline 43 & 43 & $\begin{array}{l}26.750 \\
33.250\end{array}$ & 0.068 \\
\hline 44 & $\begin{array}{l}44 \\
45\end{array}$ & $\begin{array}{r}33.250 \\
33.50\end{array}$ & 0.061 \\
\hline $\begin{array}{l}45 \\
46\end{array}$ & $\begin{array}{l}45 \\
46\end{array}$ & $\begin{array}{l}\begin{array}{l}31.500 \\
58.000\end{array}\end{array}$ & $\begin{array}{l}0.055 \\
0.108\end{array}$ \\
\hline 47 & $\begin{array}{l}46 \\
47\end{array}$ & $\begin{array}{l}5.0000 \\
31.500\end{array}$ & $\begin{array}{l}0.108 \\
0.131\end{array}$ \\
\hline 48 & 48 & 166.500 & 0.136 \\
\hline 49 & 49 & 28.500 & 0.075 \\
\hline 50 & 50 & 59.000 & 0.095 \\
\hline $\begin{array}{l}51 \\
\text { 5n }\end{array}$ & $\begin{array}{l}51 \\
\text { 5ר }\end{array}$ & 99.750 & 0.129 \\
\hline $\begin{array}{l}52 \\
53\end{array}$ & 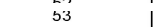 & $\begin{array}{l}557.7 n \\
80.250\end{array}$ & $\begin{array}{l}\hat{1} \\
0.121\end{array}$ \\
\hline 54 & 54 & 31.250 & 0.118 \\
\hline 55 & 55 & 49.750 & 0.120 \\
\hline 56 & 56 & 39.500 & 0.108 \\
\hline 57 & 57 & 8.250 & 0.087 \\
\hline 58 & 58 & 93.500 & 0.159 \\
\hline 59 & 59 & 40.250 & 0.132 \\
\hline 60 & 60 & 39.250 & 0.096 \\
\hline 61 & 61 & 61.000 & 0.123 \\
\hline 62 & 62 & 16.000 & 0.057 \\
\hline 63 & 63 & 27.500 & 0.116 \\
\hline 64 & 64 & 146.250 & 0.265 \\
\hline 65 & 65 & 3.750 & 0.053 \\
\hline 66 & 66 & $\begin{array}{r}45.500 \\
32500\end{array}$ & $\begin{array}{l}0.110 \\
0.102\end{array}$ \\
\hline 67 & 67 & $\begin{array}{l}32.500 \\
88.520\end{array}$ & $\begin{array}{l}0.102 \\
0.175\end{array}$ \\
\hline 68 & 68 & $\begin{array}{l}88.250 \\
79.250\end{array}$ & $\begin{array}{l}0.175 \\
0.165\end{array}$ \\
\hline $\begin{array}{l}69 \\
70\end{array}$ & $\begin{array}{l}69 \\
70\end{array}$ & $\begin{array}{r}79.250 \\
109.500\end{array}$ & $\begin{array}{l}0.165 \\
0.156\end{array}$ \\
\hline 71 & 71 & 95.000 & 0.140 \\
\hline 72 & 72 & 56.500 & 0.151 \\
\hline 73 & 73 & 29.000 & 0.132 \\
\hline 74 & 74 & 76.500 & 0.157 \\
\hline & Jumlah & $4,601.750$ & 13.358 \\
\hline
\end{tabular}

Sumber : Hasil Perhitungan
Tabel 14.Laju Erosi Metode MUSLE di DAS Oesapa Besar dengan penggunaan Lahan Existing

\begin{tabular}{|c|c|c|c|c|}
\hline No & Sub-sub DAS & $\begin{array}{l}\text { Luas } \\
(\mathrm{Ha})\end{array}$ & $\begin{array}{c}\text { Laju Erosi } \\
\text { (Ton/ha/tahun) }\end{array}$ & $\begin{array}{l}\text { Jumlah Erosi } \\
\text { A (ton/tahun) }\end{array}$ \\
\hline 1 & 2 & & & \\
\hline $\begin{array}{l}1 \\
2\end{array}$ & $\begin{array}{l}1 \\
2\end{array}$ & $\begin{array}{l}48.751 \\
30.750\end{array}$ & $\begin{array}{l}2.111 \\
1.110\end{array}$ & $\begin{array}{r}102.90 \\
34.14\end{array}$ \\
\hline 3 & 3 & $\begin{array}{l}30.500 \\
47.500\end{array}$ & 1.648 & $\begin{array}{l}34.14 \\
78.28\end{array}$ \\
\hline 4 & 4 & 2.249 & & \\
\hline 5 & 5 & 66.999 & 6.454 & 432.39 \\
\hline 6 & 6 & 56.001 & 3.040 & 170.22 \\
\hline 7 & 7 & 85.001 & 7.758 & 659.42 \\
\hline 8 & 8 & 183.504 & 31.814 & $5,837.94$ \\
\hline 9 & 9 & 171.750 & 9.904 & $1,701.00$ \\
\hline 10 & 10 & 59.250 & 4.429 & 262.41 \\
\hline 11 & 11 & 5.750 & 0.143 & 0.82 \\
\hline 12 & 12 & 35.001 & 2.857 & 100.01 \\
\hline 13 & 13 & 2.500 & 0.199 & 0.50 \\
\hline 14 & 14 & 13.501 & 0.457 & 6.17 \\
\hline 15 & 15 & $\begin{array}{r}55.000 \\
146.250\end{array}$ & $\begin{array}{r}5.671 \\
\end{array}$ & $\begin{array}{r}311.89 \\
2754.26\end{array}$ \\
\hline 16 & 16 & $\begin{array}{l}146.250 \\
134.751\end{array}$ & $\begin{array}{l}18.833 \\
15601\end{array}$ & $\begin{array}{l}2,754.26 \\
2,102.20\end{array}$ \\
\hline $\begin{array}{l}17 \\
18\end{array}$ & $\begin{array}{l}17 \\
18\end{array}$ & $\begin{array}{r}134.751 \\
97.498\end{array}$ & $\begin{array}{r}15.601 \\
5.057\end{array}$ & $\begin{array}{r}2,302.20 \\
493.02\end{array}$ \\
\hline 19 & 19 & 35.750 & 2.148 & 76.81 \\
\hline 20 & 20 & 35.751 & 2.072 & 74.06 \\
\hline 21 & 21 & 4.500 & 0.156 & 0.70 \\
\hline 22 & 22 & 98.999 & 10.286 & $1,018.35$ \\
\hline 23 & 23 & 332.751 & 46.438 & 15.452 .32 \\
\hline 24 & 24 & 43.500 & 4.017 & 174.74 \\
\hline 25 & 25 & $\begin{array}{r}35.499 \\
151251\end{array}$ & $\begin{array}{r}1.799 \\
15\end{array}$ & $\begin{array}{r}63.85 \\
228189\end{array}$ \\
\hline & $\begin{array}{l}26 \\
27\end{array}$ & $\begin{array}{r}151.251 \\
51750\end{array}$ & $\begin{array}{r}15.087 \\
2.927\end{array}$ & $\begin{array}{r}2,281.89 \\
151.45\end{array}$ \\
\hline $\begin{array}{l}27 \\
28\end{array}$ & $\begin{array}{l}27 \\
28\end{array}$ & $\begin{array}{r}51.750 \\
4.250\end{array}$ & $\begin{array}{l}2.927 \\
0.109\end{array}$ & $\begin{array}{r}151.45 \\
0.46\end{array}$ \\
\hline 29 & 29 & 109.999 & 13.668 & $1,503.44$ \\
\hline 30 & 30 & 30.000 & 1.337 & 40.10 \\
\hline 31 & 31 & 64.998 & 5.839 & 379.54 \\
\hline 32 & 32 & 28.500 & 2.145 & 61.14 \\
\hline 33 & 33 & 45.248 & 3.985 & 180.29 \\
\hline 34 & 34 & 39.249 & 2.967 & 116.44 \\
\hline & 35 & 26.248 & $\begin{array}{l}1.121 \\
2786\end{array}$ & 29.43 \\
\hline 36 & 36 & $\begin{array}{l}27.749 \\
47.249\end{array}$ & $\begin{array}{l}2.786 \\
3.927\end{array}$ & $\begin{array}{r}77.32 \\
18553\end{array}$ \\
\hline 37 & 37 & 47.249 & $\begin{array}{l}3.927 \\
3.970\end{array}$ & 185.53 \\
\hline $\begin{array}{l}38 \\
39\end{array}$ & $\begin{array}{l}38 \\
39\end{array}$ & $\begin{array}{r}44.500 \\
105.251\end{array}$ & $\begin{array}{r}3.970 \\
14.669\end{array}$ & $\begin{array}{r}176.67 \\
1,543.92\end{array}$ \\
\hline 40 & 40 & 30.999 & 2.899 & 89.88 \\
\hline 41 & 41 & 79.750 & 8.775 & 699.79 \\
\hline 42 & 42 & 37.000 & 1.224 & 45.29 \\
\hline 43 & 43 & 26.750 & 0.381 & 10.20 \\
\hline 44 & 44 & 33.250 & 0.564 & 18.74 \\
\hline 45 & 45 & 31.498 & 0.389 & 12.25 \\
\hline 46 & 46 & 58.001 & 3.511 & 203.62 \\
\hline 47 & 47 & 31.501 & 1.821 & 57.37 \\
\hline 48 & 48 & 166.500 & 12.435 & $2,070.45$ \\
\hline 49 & 49 & $\begin{array}{r}28.500 \\
558\end{array}$ & 0.855 & 24.38 \\
\hline $\begin{array}{l}50 \\
51\end{array}$ & $\begin{array}{l}50 \\
51\end{array}$ & $\begin{array}{l}58.999 \\
99751\end{array}$ & $\begin{array}{l}2.116 \\
5.692\end{array}$ & $\begin{array}{l}124.87 \\
567.77\end{array}$ \\
\hline 52 & 52 & 65.750 & 4.286 & 281.80 \\
\hline 53 & 53 & 80.250 & 3.774 & 302.89 \\
\hline 54 & 54 & 31.251 & 1.600 & 50.01 \\
\hline 55 & 55 & 49.751 & 3.297 & 164.01 \\
\hline 56 & 56 & 39.501 & 1.914 & 75.60 \\
\hline 57 & 57 & 8.250 & 0.361 & 2.98 \\
\hline 58 & 58 & 93.500 & 10.820 & $1,011.65$ \\
\hline 59 & 59 & 40.249 & 2.930 & 117.93 \\
\hline 60 & 60 & 39.250 & 1.221 & 47.93 \\
\hline 61 & 61 & 60.999 & 3.198 & 195.06 \\
\hline 62 & 62 & 15.999 & 0.387 & 6.20 \\
\hline 63 & 63 & 27.500 & 1.144 & 31.45 \\
\hline 64 & 64 & 146.251 & 20.936 & $3,061.95$ \\
\hline 65 & 65 & 3.750 & 0.093 & 0.35 \\
\hline 66 & 66 & 45.500 & 2.003 & 91.15 \\
\hline 67 & 67 & 32.500 & 2.877 & 93.50 \\
\hline 68 & 68 & 88.252 & 13.203 & $1,165.21$ \\
\hline 69 & 69 & 79.250 & 11.355 & 899.90 \\
\hline 70 & 70 & 109.500 & 13.811 & $1,512.29$ \\
\hline 71 & 71 & 95.000 & 11.179 & $1,062.03$ \\
\hline 72 & 72 & 56.501 & 7.369 & 416.36 \\
\hline 73 & 73 & 29.000 & 3.425 & 99.33 \\
\hline \multirow{2}{*}{74} & 74 & 76.499 & 5.388 & 412.20 \\
\hline & & $4,601.750$ & 425.771 & $53,662.43$ \\
\hline
\end{tabular}

Sumber : Hasil Analisa

\section{c. Analisa Indeks Bahaya Erosi DAS Oesapa Besar}

Indeks bahaya erosi dapat ditentukan sebagaimana contoh Perhitungan pada perhitungan sebagai berikut : 
Data pada Sub-sub DAS 1 :

Erosi Potensial $(\mathrm{A}) \quad=2.111($ ton $/ \mathrm{ha} /$ tahun $)$

Berat Volume Tanah $=1,2$ gram $/ \mathrm{cc}$

Nilai Erosi yang diizinkan $=2 \mathrm{~mm} / \mathrm{tahun}$

$$
\begin{aligned}
& =2 \times 1,2 \times 10 \\
& =24(\text { ton/ha/tahun })
\end{aligned}
$$

$$
\begin{aligned}
\text { maka Indeks Bahaya Erosi } & =\frac{2,111}{24} \\
& =, 0,088
\end{aligned}
$$

Sesuai tabel Klasifikasi Indeks Bahaya Erosi maka harkat untuk Indeks Bahaya Erosi sebesar 0,088 adalah Rendah. Hasil penggambaran pada Gambar 5.8,

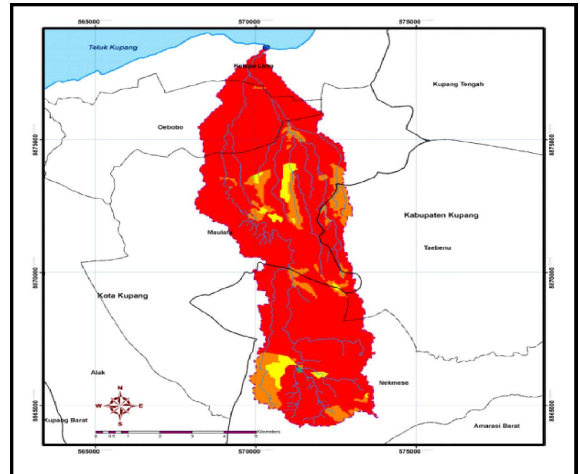

Gambar 4.1. Tingkat Bahaya Erosi DAS Oesapa Besar

\section{d. Penentuan Lokasi Bangunan Pengendali Sedimen ( Check Dam)}

Penentuan letak lokasi bangunan Pengendali Sedimen (BPS) dalam peneletian ini rekomendasi penempatan lokasi sesuai Gambar.

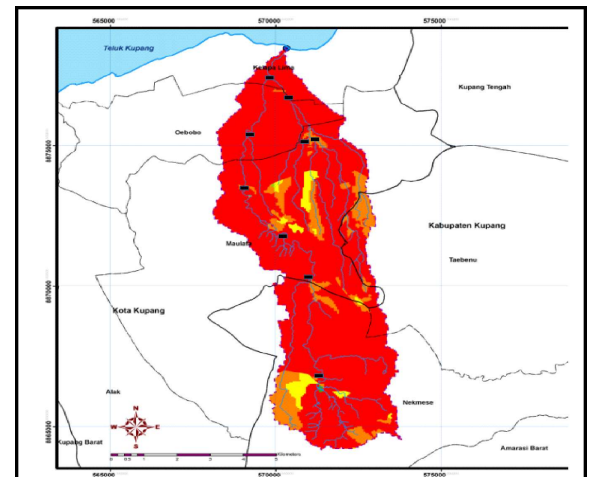

Gambar 5.13. Peta Rekomendasi Letak Dam Pengendali ( Check Dam ) DAS Oesapa Besar
Tabel 5.15. Rekomendasi Letak Lokasi Dam Pengendali

\begin{tabular}{|c|c|c|c|c|c|c|c|c|}
\hline \multirow{2}{*}{ No } & Sub & \multicolumn{2}{|c|}{ Koordinat(UTM Zone 51 S) } & Koordinat (Geografi) & Desa / & \multirow{2}{*}{ Kecamatan } & Kabupaten I \\
& DAS & Kota \\
\hline 1 & 1 & 571469.17 & 8866257.53 & 123.652 & 10.256 & Naimata & Maulafa & Kota. Kupang \\
2 & 9 & 571184.58 & 8866211.79 & 123.650 & 10.256 & Naimata & Maulafa & Kota. Kupang \\
3 & 16 & 570996.55 & 8869281.30 & 123.648 & 10.228 & Oelamin & Nekmese & Kab. Kupang \\
4 & 20 & 570595.07 & 8869997.85 & 123.644 & 10.222 & Naimata & Maulafa & Kota Kupang \\
5 & 23 & 571357.37 & 8873194.40 & 123.651 & 10.193 & Penfui & Kelapa Lima & Kab. Kupang \\
6 & 29 & 572150.15 & 8873001.29 & 123.658 & 10.195 & Naimata & Maulafa & Kota Kupang \\
7 & 41 & 569294.09 & 8875704.89 & 123.632 & 10.170 & Oebufu & Oebobo & Kota Kupang \\
8 & 50 & 569085.73 & 8873707.68 & 123.630 & 10.188 & Tunfeu & Kupang Tengah & Kab. Kupang \\
9 & 64 & 570666.22 & 8873331.62 & 123.645 & 10.192 & Bismark & Kupang Tengah & Kab. Kupang \\
\hline
\end{tabular}

Sumber : Hasil Analisa

\begin{tabular}{|c|c|c|c|c|c|c|}
\hline Sub & & Erosi DAS Osapa & & & ata Dari Pembuatan DE & \\
\hline DAS & Luas (Ha) & Laju Erosi (tonhalith) & Jumlah Erosi (tonith) & Slope Lereng $(\%)$ & Panjang Sungai (m) & Slope Sungai $(\%)$ \\
\hline 1 & 48.75 & 2.111 & 102.90 & 14.49 & $\begin{array}{r}2,323.59 \\
\end{array}$ & 1.16 \\
\hline 2 & 30.75 & 1.110 & 34.14 & 6.22 & 695.99 & 5.40 \\
\hline 3 & 47.50 & 1.648 & 78.28 & 1.98 & $1,019.99$ & 0.51 \\
\hline 4 & 2.25 & - & - & . & 50.00 & 0.10 \\
\hline 5 & 67.00 & 6.454 & 432.39 & 2.90 & 795.03 & 3.23 \\
\hline 6 & 56.00 & 3.040 & 170.22 & 3.79 & 553.57 & 3.21 \\
\hline 7 & 85.00 & 7.758 & 659.42 & 2.82 & $1,078.02$ & 0.76 \\
\hline 8 & 183.50 & 31.814 & $5,837.94$ & 8.08 & $1,518.12$ & 1.52 \\
\hline 9 & 171.75 & 9.904 & $1,701.00$ & 13.57 & $1,980.23$ & 3.27 \\
\hline 10 & 59.25 & 4.429 & 262.41 & 3.20 & $1,890.17$ & 1.93 \\
\hline 11 & 5.75 & 0.143 & 0.82 & 2.09 & $1,015.99$ & 4.17 \\
\hline 12 & 35.00 & 2.857 & 100.01 & 2.15 & 170.71 & 2.46 \\
\hline 13 & 2.50 & 0.199 & 0.50 & 3.28 & 241.42 & 0.10 \\
\hline 14 & 13.50 & 0.457 & 6.17 & 2.90 & $1,948.49$ & 0.11 \\
\hline 15 & 55.00 & 5.671 & 311.89 & 12.88 & 353.76 & 4.59 \\
\hline 16 & 146.25 & 18.833 & $2,754.26$ & 13.10 & $1,066.81$ & 5.38 \\
\hline 17 & 134.75 & 15.601 & $2,102.20$ & 9.41 & 610.84 & 5.33 \\
\hline 18 & 97.50 & 5.057 & 493.02 & 6.29 & $1,400.70$ & 3.93 \\
\hline 19 & 35.75 & 2.148 & 76.81 & 7.79 & $1,588.17$ & 4.53 \\
\hline 20 & 35.75 & 2.072 & 74.06 & 12.97 & $1,811.69$ & 4.74 \\
\hline 21 & 4.50 & 0.156 & 0.70 & 2.92 & 933.64 & 3.46 \\
\hline 22 & 99.00 & 10.286 & $1,018.35$ & 8.06 & 171.17 & 4.96 \\
\hline 23 & 332.75 & 46.438 & $15,452.32$ & 15.25 & $1,824.66$ & 4.56 \\
\hline 24 & 43.50 & 4.017 & 174.74 & 6.11 & 468.87 & 6.34 \\
\hline 25 & 35.50 & 1.799 & 63.85 & 11.90 & 2,017.43 & 4.14 \\
\hline 26 & 151.25 & 15.087 & $2,281.89$ & 14.76 & 346.14 & 4.44 \\
\hline 27 & 51.75 & 2.927 & 151.45 & 12.45 & $2,729.24$ & 6.22 \\
\hline 28 & 4.25 & 0.109 & 0.46 & 6.48 & $3,053.90$ & 7.32 \\
\hline 29 & 110.00 & 13.668 & $1,503.44$ & 14.42 & $3,711.83$ & 2.66 \\
\hline 30 & 30.00 & 1.337 & 40.10 & 4.89 & $1,401.97$ & 5.34 \\
\hline 31 & 65.00 & 5.839 & 379.54 & 5.74 & $1,000.76$ & 4.48 \\
\hline 32 & 28.50 & 2.145 & 61.14 & 9.93 & $1,882.04$ & 4.99 \\
\hline 33 & 45.25 & 3.985 & 180.29 & 6.94 & 195.71 & 5.48 \\
\hline 34 & 39.25 & 2.967 & 116.44 & 13.31 & 582.84 & 0.10 \\
\hline 35 & 26.25 & 1.121 & 29.43 & 10.09 & 267.95 & 0.10 \\
\hline 36 & 27.75 & 2.786 & 77.32 & 8.35 & 824.37 & 10.71 \\
\hline 37 & 47.25 & 3.927 & 185.53 & 13.63 & 246.03 & 1.57 \\
\hline 38 & 44.50 & 3.970 & 176.67 & 11.95 & $1,307.17$ & 5.09 \\
\hline 39 & 105.25 & 14.669 & $1,543.92$ & 14.07 & 196.11 & 0.96 \\
\hline 40 & 31.00 & 2.899 & 89.88 & 17.86 & $3,934.51$ & 6.39 \\
\hline 41 & 79.75 & 8.775 & 699.79 & 16.07 & 924.44 & 1.98 \\
\hline 42 & 37.00 & 1.224 & 45.29 & 11.18 & 491.47 & 10.07 \\
\hline 43 & 26.75 & 0.381 & 10.20 & 14.82 & 908.12 & 1.37 \\
\hline 44 & 33.25 & 0.564 & 18.74 & 14.77 & 713.95 & 3.37 \\
\hline 45 & 31.50 & 0.389 & 12.25 & 17.14 & 106.12 & 7.16 \\
\hline 46 & 58.00 & 3.511 & 203.62 & 9.97 & 6,368.61 & 13.90 \\
\hline 47 & 31.50 & 1.821 & 57.37 & 1.98 & 176.25 & 3.07 \\
\hline 48 & 166.50 & 12.435 & $2,070.45$ & 3.45 & 370.92 & 1.95 \\
\hline 49 & 28.50 & 0.855 & 24.38 & 16.13 & 991.55 & 11.98 \\
\hline 50 & 59.00 & 2.116 & 124.87 & 11.11 & $3,495.46$ & 8.00 \\
\hline
\end{tabular}

Tabel 15. Laju Erosi, Jumlah Erosi, Slope Lereng, Panjang Sungai dan Slope Sungai Hasil Pembuatan DEM 


\begin{tabular}{|c|c|c|c|c|c|c|}
\hline 51 & 99.75 & 5.692 & 567.77 & 10.91 & $1,269.72$ & 8.57 \\
\hline 52 & 65.75 & 4.286 & 281.80 & 6.89 & 629.13 & 4.28 \\
\hline 53 & 80.25 & 3.774 & 302.89 & 3.90 & 245.72 & 0.91 \\
\hline 54 & 31.25 & 1.600 & 50.01 & 6.02 & 500.11 & 0.91 \\
\hline 55 & 49.75 & 3.297 & 164.01 & 5.32 & 872.56 & 4.30 \\
\hline 56 & 39.50 & 1.914 & 75.60 & 3.62 & 220.99 & 2.05 \\
\hline 57 & 8.25 & 0.361 & 2.98 & 7.63 & $1,369.30$ & 5.01 \\
\hline 58 & 93.50 & 10.820 & $1,0111.65$ & 4.15 & 924.67 & 2.22 \\
\hline 59 & 40.25 & 2.930 & 117.93 & 6.28 & $1,120.25$ & 0.34 \\
\hline 60 & 39.25 & 1.221 & 47.93 & 3.36 & 557.85 & 2.95 \\
\hline 61 & 61.00 & 3.198 & 195.06 & 5.06 & 795.07 & 1.57 \\
\hline 62 & 16.00 & 0.387 & 6.20 & 3.32 & 195.71 & 0.10 \\
\hline 63 & 27.50 & 1.144 & 31.45 & 5.40 & 262.13 & 0.10 \\
\hline 64 & 146.25 & 20.936 & $3,061.95$ & 10.75 & $3,307.21$ & 2.52 \\
\hline 65 & 3.75 & 0.093 & 0.35 & 1.68 & $4,018.53$ & 0.10 \\
\hline 66 & 45.50 & 2.003 & 91.15 & 6.31 & 156.07 & 1.56 \\
\hline 67 & 32.50 & 2.877 & 93.50 & 3.03 & 803.65 & 0.10 \\
\hline 68 & 88.25 & 13.203 & $1,165.21$ & 10.97 & $1,322.70$ & 2.69 \\
\hline 69 & 79.25 & 11.355 & 899.90 & 6.16 & $1,001.74$ & 3.75 \\
\hline 70 & 109.50 & 13.811 & $1,5122.29$ & 9.02 & $1,614.92$ & 4.65 \\
\hline 71 & 95.00 & 11.179 & $1,062.03$ & 10.08 & $1,861.33$ & 3.78 \\
\hline 72 & 56.50 & 7.369 & 416.36 & 8.47 & $1,984.51$ & 0.28 \\
\hline 73 & 29.00 & 3.425 & 99.33 & 9.99 & 226.84 & 2.33 \\
\hline 74 & 76.50 & 5.388 & 412.20 & 4.99 & 457.84 & 0.94 \\
\hline Jumla & $4,601.75$ & 425.771 & $53,662.43$ & & & \\
\hline
\end{tabular}

Sumber : Hasil Analisis

\section{e. Perhitungan Volume Tampungan dan Usia Bendungan Pengendali Sedimen}

Cara pendekatan yang digunakan dalam perencanaan volume sedimen dengan metode didasarkan pada topografi dan tinggi bangunan dengan menggunakan persamaan sebagai berikut :
Tabel 16. Perhitungan Volume Tampungan Bangunan Pengendali Sedimen Sub DAS Oesapa Besar

\begin{tabular}{|c|c|c|c|c|c|}
\hline No & $\begin{array}{c}\text { Lokasi } \\
\text { Sub DAS }\end{array}$ & $\begin{array}{c}\text { Panjang } \\
\text { Check Dam }(\mathrm{B}) \\
(\mathrm{m})\end{array}$ & $\begin{array}{c}\text { Tinggi } \\
\text { Check Dam }(\mathrm{H}) \\
(\mathrm{m})\end{array}$ & $\begin{array}{c}\text { Panjang Aliran } \\
\text { Sungai (Lt) } \\
(\mathrm{m})\end{array}$ & $\begin{array}{c}\text { Volume } \\
\text { Tamp. Sedimen } \\
(\mathrm{m} 3)\end{array}$ \\
\hline 1 & 2 & 3 & 4 & 5 & 6 \\
\hline 1 & 1 & 166.21 & 9.54 & $2,323.59$ & $3,683,896.94$ \\
2 & 9 & 148.74 & 7.57 & $1,518.12$ & $1,709,056.00$ \\
3 & 16 & 119.16 & 5.33 & $1,066.81$ & $1,974,023.98$ \\
4 & 20 & 177.75 & 9.06 & $1,811.69$ & $2,916,571.48$ \\
5 & 23 & 151.12 & 9.12 & $1,824.66$ & $3,272,164.00$ \\
6 & 29 & 124.30 & 6.47 & $1,307.17$ & $1,051,597.94$ \\
7 & 41 & 90.25 & 4.77 & 991.55 & $1,436,242.99$ \\
8 & 50 & 129.35 & 4.62 & 924.67 & $552,985.11$ \\
9 & 64 & 168.32 & 6.53 & $1,322.70$ & $1,453,457.45$ \\
\hline \multicolumn{7}{|c|}{ Total Volume Tampungan } \\
\hline \multicolumn{7}{|c|}{}
\end{tabular}

Sumber : Hasil Perhitungan

\section{f. Perhitungan Usia Bangunan Pengendali Sedimen}

Adapun usia bendungan disajikan pada Tabel 17

Tabel 17. Perhitungan Usia Bangunan Pengendali Sedimen Sub DAS Oesapa Besar

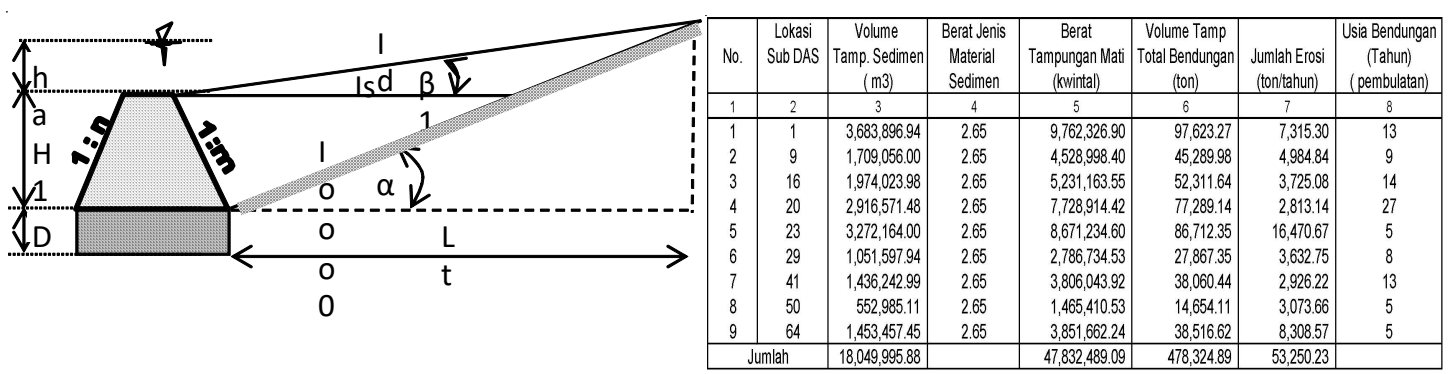

Tampungan total dihitung dengan rumus :

$\mathrm{Vt}=1 / 2 \mathrm{~B} \mathrm{H} \mathrm{Lt}$

$\mathrm{Vt}=$ Volume total tampungan sedimen

$\mathrm{B}=$ Panjang bangunan pengendali sedimen

$\mathrm{H}=$ Tinggi total bangunan pelimpah

Lt $=$ Panjang sungai arah ke hulu

Panjang bangunan pengendali sedimen $(\mathrm{B})=$ $166,21 \mathrm{~m}$, Tinggi bangunan pengendali sedimen $=9,54 \mathrm{~m}$, Panjang sungai arah ke hulu $=$ 2,323.59 $\mathrm{m}$ (hasil analisis atribut $D E M$ pada Tabel 5.17), $\mathrm{Vt}=1 / 2 \mathrm{~B} \mathrm{H} \mathrm{Lt},=(1 / 2166,21)=$ $9,542.323,59, \mathrm{Vt}=3.683 .896,94 \mathrm{~m}^{3}$.

Sumber : Hasil Perhitungan

\section{KESIMPULAN}

Berdasarkan hasil análisis sesuai pembahasan dalam penelitian ini, dapat diambil kesimpulan sebagai berikut :

1. Merekomendasikan jumlah bangunan pengendali sedimen di DAS Oesapa Besar untuk mengurangi laju erosi dengan kondisi di lapangan guna mencegah bencana pada bagian hilir sebanyak 9 Lokasi dengan penempatan lokasi sesuai koordinat UTM Zone $51 \mathrm{~S}$ dan koordinat topografi serta Desa, Kecamatan sebagai berikut : 


\begin{tabular}{|c|c|c|c|c|c|c|c|c|}
\hline \multirow{2}{*}{ No } & Sub & \multicolumn{2}{|c|}{ Koordinat (UTM Zone 51 S) } & \multicolumn{2}{|c|}{ Koordinat (Geografi) } & Desa/ & \multirow{2}{*}{ Kelamatan } & Kabupaten / \\
& DAS & $\mathrm{X}$ & $\mathrm{Y}$ & $\mathrm{BT}$ & LS & Kelurahan & & Kota \\
\hline 1 & 1 & 571469.17 & 8866257.53 & 123.652 & 10.256 & Naimata & Maulafa & Kota. Kupang \\
2 & 9 & 571184.58 & 8866211.79 & 123.650 & 10.256 & Naimata & Maulafa & Kota. Kupang \\
3 & 16 & 570996.55 & 8869281.30 & 123.648 & 10.228 & Oelamin & Nekmese & Kab. Kupang \\
4 & 20 & 570595.07 & 8869997.85 & 123.644 & 10.222 & Naimata & Maulafa & Kota Kupang \\
5 & 23 & 571357.37 & 88731944.40 & 123.651 & 10.193 & Penfui & Kelapa Lima & Kab. Kupang \\
6 & 29 & 572150.15 & 8873001.29 & 123.658 & 10.195 & Naimata & Maulafa & Kota Kupang \\
7 & 41 & 569294.09 & 8875704.89 & 123.632 & 10.170 & Oebufu & Oebobo & Kota Kupang \\
8 & 50 & 569085.73 & 8873707.68 & 123.630 & 10.188 & Tunfeu & Kupang Tengah & Kab. Kupang \\
9 & 64 & 570666.22 & 8873331.62 & 123.645 & 10.192 & Bismark & Kupang Tengah & Kab. Kupang \\
\hline
\end{tabular}

Adapun lokasi penempatan sesuai hasil analisis masing-masing Sub DAS tersebut diatas ditampilkan pada Gambar di bawah ini :

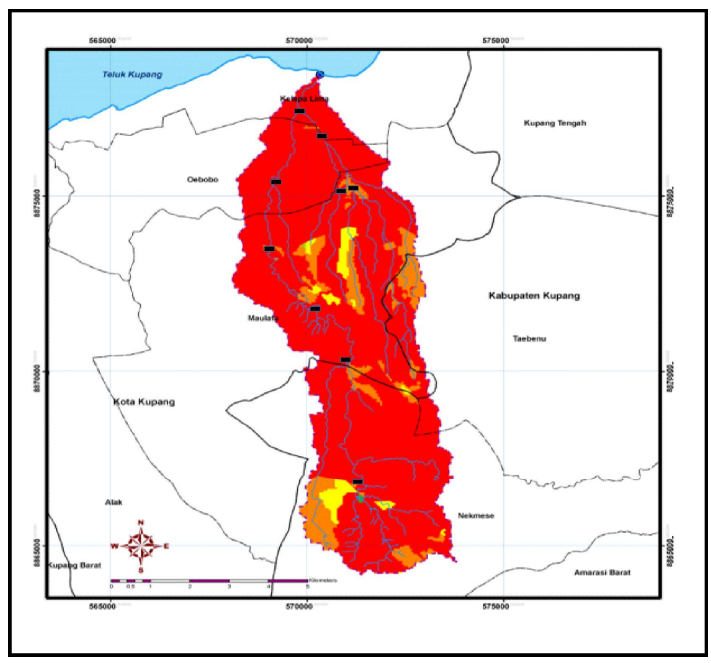

Lokasi Penempatan Bangunan Pengendali Sedimen di DAS Oesapa Besar

2. Desain bangunan pengendali sedimen yang cocok sesuai kondisi eksisting di DAS Oesapa Besar dengan kondisi di lapangan pada tahun 2015 adalah:

Desain bangunan check dam yang dilakukan dalam rangka menghasilkan suatu bangunan fungsional yang optimal dengan total biaya minimum. Untuk mencapai biaya dari hasil analisa sebelumnya setelah diketahui arahan penempatan lokasi bangunan pengendali sedimen diperoleh bahwa terdapat 9 lokasi Check Dam (Dam Pengendali) untuk menahan laju erosi yang terjadi di DAS Oesapa Besar.
3. Usia masing-masing bangunan pengendali sedimen sesuai penempatan dan laju erosi yang terjadi pada Sub-Sub DAS Oesapa Besar sebagai berikut :

\begin{tabular}{|c|c|c|c|c|c|c|c|}
\hline №. & $\begin{array}{c}\text { Lokasi } \\
\text { Sub DAS }\end{array}$ & \begin{tabular}{|c|}
$\begin{array}{c}\text { Volume } \\
\text { Tamp. Sedimen } \\
(\mathrm{m} 3)\end{array}$ \\
\end{tabular} & $\begin{array}{l}\text { Berat Jenis } \\
\text { Material } \\
\text { Sedimen }\end{array}$ & \begin{tabular}{|c|} 
Berat \\
Tampungan Mati \\
(kwintal)
\end{tabular} & \begin{tabular}{|c|}
$\begin{array}{c}\text { Volume Tamp } \\
\text { Total Bendungan } \\
\text { (ton) }\end{array}$ \\
\end{tabular} & $\begin{array}{c}\text { Jumlah Erosi } \\
\text { (tonltahun) }\end{array}$ & $\begin{array}{c}\text { Usia Bendungan } \\
\text { (Tahun) } \\
\text { (pembulatan) }\end{array}$ \\
\hline 1 & 2 & 3 & 4 & \begin{tabular}{|l} 
\\
\end{tabular} & \begin{tabular}{|l|}
6 \\
\end{tabular} & 7 & 8 \\
\hline 1 & 1 & $3,683,896.94$ & 2.65 & $9,762,326.90$ & $97,623.27$ & $7,315.30$ & 13 \\
\hline 2 & 9 & $1,709,056.00$ & 2.65 & $4,528,998.40$ & $45,289.98$ & 4,984.84 & 9 \\
\hline 3 & 16 & $1,974,023.98$ & 2.65 & $5,231,163.55$ & $52,311.64$ & $3,725.08$ & 14 \\
\hline 4 & 20 & $2,916,571.48$ & 2.65 & $7,728,914.42$ & $77,289.14$ & $2,813.14$ & 27 \\
\hline 5 & 23 & $3,272,164.00$ & 2.65 & $8,671,234,60$ & $86,712,35$ & $16,470.67$ & 5 \\
\hline 6 & 29 & $1,051,597.94$ & 2.65 & $2,786,734.53$ & $27,867,35$ & $3,632.75$ & 8 \\
\hline 7 & 41 & $1,436,242.99$ & 2.65 & $3,806,043.92$ & $38,060.44$ & $2,926.22$ & 13 \\
\hline 8 & 50 & $552,985.11$ & 2.65 & $1,465,410.53$ & $14,654.11$ & $3,073.66$ & 5 \\
\hline 9 & 64 & $1,453,457.45$ & 2.65 & $3,851,662.24$ & $38,516,62$ & $8,308.57$ & 5 \\
\hline \multicolumn{2}{|c|}{ Jumlah } & $18,049,995.88$ & & $47,832,489.09$ & $478,324.89$ & $53,250.23$ & \\
\hline
\end{tabular}

\section{DAFTAR PUSTAKA}

Aronoff. 1989. Geographic Information System - A Management Perspective. Ottawa : WDL Publications.

Asdak, Chay. 2004. Hidrologi Dan Pengelolaan Daerah Aliran Sungai. Yogyakarta : Gajah Mada University Press.

Bisri, Mohammad, 2009 Pengelolaan Daerah Aliran Sungai, Malang : Penerbit Percetakan CV. Asrori.

ESRI (Environmental System Research Institute, Inc). 1996. Arc View GIS, The Geographic Information System for Everyone. New York : ESRI.

Marwan, Achmad. 2003. "Implementasi Sistem Informasi Geografis Dalam Penentuan Batas Genangan Bendungan Genteng Kecamatan Dampit, Kabupaten Malang". Skripsi tidak diterbitkan. Malang : Jurusan Pengairan FT Unibraw, 2003.

Prahasta, Eddy. 2001. Konsep-Konsep Dasar Sistem Informasi Geografis. Bandung : CV Informatika.

Prahasta, Eddy. 2005. Sistem Informasi Geografis. Bandung : CV Informatika.

Soemarto, CD. 1999. Hidrologi Teknik Edisi Kedua. Jakarta : Erlangga.

Undang Undang RI No. 7 Tahun 2004 tentang Sumber Daya Air. Pustaka Widyatama. Yogyakarta.

Utomo, Wani Hadi. 1994. Erosi Dan Konservasi Tanah. Malang : IKIP Malang. 